Reprod. Nutr. Dévelop., 1981, 21 (3), 455-465.

\title{
A reinvestigation of hypothalamic-pituitary testicular interactions : simultaneous changes in tissue and plasma levels of gonadotrophins, prolactin, testosterone and hypothalamic LH-RH after bilateral orchidectomy and cryptorchidism
}

par A. CARATY, Marie-Madeleine de REVIERS, Nadine MARTINAT, M. R. BLANC

Station de Physiologie de la Reproduction, I.N.R.A. Nouzilly 37380 Monnaie, France.

Summary. Plasma concentrations of LH, FSH, prolactin and testosterone, pituitary concentrations of gonadotrophins and prolactin, and hypothalamic LH-RH were measured in normal, sexually mature male rats at regular intervals from 1 to 30 days after castration or cryptorchidism. Bilateral castration resulted in a marked decrease in testosterone levels $24 \mathrm{~h}$ after surgery. On the contrary, plasma testosterone was increased (at days 4 and 8 ) or unaffected by cryptorchidism when compared to intact controls. From day 1 , castrated rats showed a rapid, marked increase in plasma LH and FSH (7 and 5 times higher at day 30 for $\mathrm{LH}$ and $\mathrm{FSH}$, respectively) and a delayed, progressive increase in pituitary gonadotrophins (significant at day 8 and day 30 for $\mathrm{LH}$ and FSH, respectively). The cryptorchid animals showed similar but slower and less marked changes in plasma and pituitary FSH and LH levels. Unlike plasma prolactin levels, which were lowered at day 8 or days 4,8 and 30 , respectively, after castration or cryptorchidism, no change was observed in pituitary prolactin content.

After castration, hypothalamic LH-RH content was significantly lower at day 4 and gradually decreased until day 30 . On the other hand, no changes were observed after cryptorchidism.

The present observations indicate that factors other than testosterone, associated with the presence of an active seminiferous epithelium, are involved in the regulation of gonadotrophin secretion. These factors do not seem to change the hypothalamic LH-RH content.

\section{Introduction.}

The dual function of the testis is well recognized, but the complex hormonal and neurohormonal processes involved in regulating testicular functions are still only partly understood. Surgical induction of cryptorchidism in the adult rat reduces the weights of the testis and the accessory glands (Amatayakul et al., 1971 ; Swerdloff et al., 1971).

Moreover, plasma gonadotrophin levels are increased shortly after surgery (Amatayakul et al., 1971 ; Gomes and Jain, 1976), while pituitary concentrations 
change after a longer time-lag (Steinberger and Duckett, 1966 ; Amatayakul et al., 1971). There is little agreement on the effect of experimental cryptorchidism on plasma testosterone levels : Amatayakul et al. (1971) and Kerr, Rich and de Kretser (1979) found these levels depressed by about 50 p. 100 from day 7 to day 8 after surgery, while Gomes and Jain (1976) and Hopkinson et al. (1979) found the levels were unchanged for 30 days. Furthermore, at 30 days, the seminal vesicle weights were not lower (Amatayakul ef al., 1971 ; Gomes and Jain, 1976). As the damage to the seminiferous tubule, induced by cryptorchidism, seems to be established at around day 14 (Clegg, 1963 ; Amatayakul et al., 1971), it was thought interesting to reexamine the effects of cryptorchidism on some of the hypothalamo-hypophyseal functions by comparing these effects to those of castration, paying special attention to the first two post-operative weeks. Thus, plasma levels of gonadotrophins (FSH and LH), prolactin (PRL) and testosterone and pituitary levels of FSH, LH and PRL, as well as hypothalamic levels of luteinizing hormone-releasing hormone (LH-RH), were measured at intervals after surgery.

\section{Material and methods.}

Adult male Wistar rats (INRA strain 03), 120 days old and weighing 400 to $450 \mathrm{~g}$, were kept in a controlled light environment (14 hrs light-10 hrs dark) throughout this study.

Nembutal anaesthesia ( $5 \mathrm{mg} / 100 \mathrm{~g}$ body weight) was used for all surgical procedures.

A total of 144 rats was randomly divided into three groups :

1) Cryptorchid group : the testes and their appendages were gently lifted out of the scrotal sac through a midline abdominal incision and placed in the abdominal cavity after severing the gubernaculum. The inguinal canal and the scrotal sac were then completely obliterated with silk purse sutures. Repeated examination showed that the testes did not return to the scrotum and were not ischaemic.

2) Castrated group : ablation of the testes and the epididymides was performed via the scrotal route.

3) Sham-operated group : the animals were submitted to an operation similar to that performed in the cryptorchid group, except that the gubernaculum was not severed and the scrotal sac and inguinal canal were left open. On repeated occasions after surgery, the testes were observed in the scrotal position.

Eight rats in each group were slaughtered by rapid decapitation between $09.00 \mathrm{hr}$ and $10.30 \mathrm{hrs}, 1,2,4,8,15$ and 30 days after surgery. The pituitary, hypothalamus and blood were collected from each animal. The anterior pituitaries from each group of 8 animals were pooled, homogenized in deionized water, lyophilized, extracted with saline and frozen until assay. Each hypothalamus, including the pituitary stalk, was collected immediately after decapitation, homogenized in cold $0.1 \mathrm{~N} \mathrm{HCl}$, sonicated (15" at maximal power using a MSE $150 \mathrm{~W}$ ultrasonic disintegrator) and frozen. The limits of the hypothalamic samples were defined as the optic chiasma rostrally, the hypothalamic fissures laterally and the mamillary bodies posteriorly. Each hypothalamic section was approximately 2 to $3 \mathrm{~mm}$ in depth. Blood samples were collected 
under heparin and after centrifugation at $4{ }^{\circ} \mathrm{C}$, the plasmas were stored at $-20^{\circ} \mathrm{C}$ until assayed.

LH-RH content was estimated by a specific radioimmunoassay (Caraty et al., 1980). The intra-assay coefficient of variation was 8 p. 100 and the detection limit was 0.4 pg per tube.

Pituitaries and plasma were analyzed for FSH content using the NIAMDD radioimmunoassay kit. The results are expressed in terms of NIAMDD rat FSH-RP 1.

Pituitary and plasma LH contents were measured using a specific double antibody radioimmunoassay method (Viguier-Martinez and Hochereau-de-Reviers, 1977). One unit of the purified hormone used for radioiodination and standard (LHS $\times 1-1)$ * was equivalent to 1.58 unit of NIH-LH S 11.

Plasma and pituitary prolactin levels were measured using a specific raioimmunoassay method (Martinat ef al., 1979). The intra-assay coefficient of variation was $10 \mathrm{p} .100$ and the detection limit was $0.32 \mathrm{ng} / \mathrm{ml}$ plasma. The potency of the standard (PRL-INRA) was about twice that of the NIAMDD-rat PRL-RP 1. Plasma testosterone was measured after solvent extraction ( $3 \mathrm{ml}$ ethyl ether per $0.1 \mathrm{ml}$ plasma) using a radioimmunoassay method (Picaper, in preparation). Antibody was obtained in the rabbit by injection of testosterone 3 (0-carboxymethyl)-oxime conjugated to bovine serum albumin. The cross-reactions of the antiserum were : 49 p. 100 with $5 \alpha$-dihydrotesterone ; 1.9 p. 100 with $\Delta_{4}$-androstenedione ; $<1$ p. 100 with progesterone, œstradiol, cortisol and $3 \alpha$ and $3 \beta$-androstanediol. The intra-assay coefficient of variations was 6 p. 100 and the detection limit $50 \mathrm{pg} / \mathrm{ml}$.

All the samples of each hormone were processed in duplicate (plasma) or quadriplicate at five doses (pituitaries) in a single assay. The hormone concentrations of plasma samples were determined using logit-log transformation. Only those two of the five doses of pituitary extracts nearest the $B / B_{o}=50$ p. 100 were used for a 4-point assay (Emmens, 1948). The results were expressed in terms of standard per $\mathrm{mg}$ lyophilized powder. A comparison of means between the experimental and the control groups was conducted using the t-fest for independent means (Snedecor, 1956).

\section{Results.}

Plasma and pituitary levels of $\mathrm{LH}$ (figs. 1a-2b). - After gonadectomy, a rapid and marked increase in plasma LH occurred between day $1(P<0.01)$ and day 15 $(P<0.001)$. These elevated levels then remained roughly constant between day 15 and day 30 (about 7 times the levels of the sham-operated animals). Twenty-four hours after surgery, pituitary LH concentration was significantly $(P<0.05)$ lower, but a progressive increase in pituitary concentration was noticeable from day $8(P<0.05)$ until day $30(P<0.001)$. At that time, the pituitary LH concentration of the castrated group was three fold greater than that of the sham-operated animals.

In cryptorchid animals, plasma LH levels rose between day 8 and day 15 ; the values then remained approximately constant (from day 15 to day 30 ) at about twice those of the levels observed in sham-operated rats. Pifuitary LH content was only significantly $(P<0.001)$ greater than in sham-operated controls at day 30.

* From Dr. Jutisz, CNRS, Gif-sur-Yvette, France. 


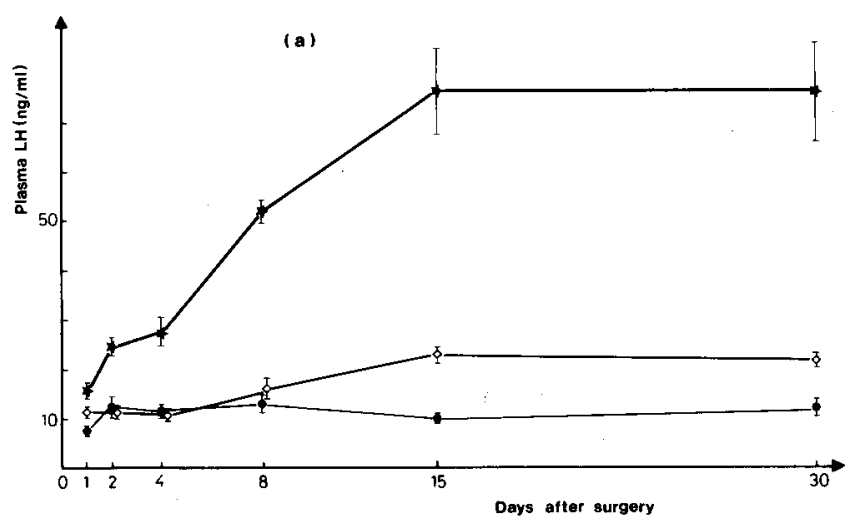

(c)

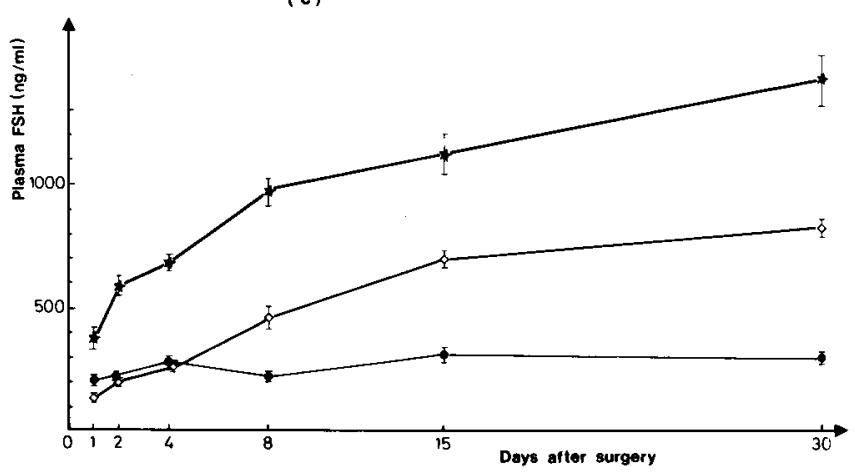

(e)

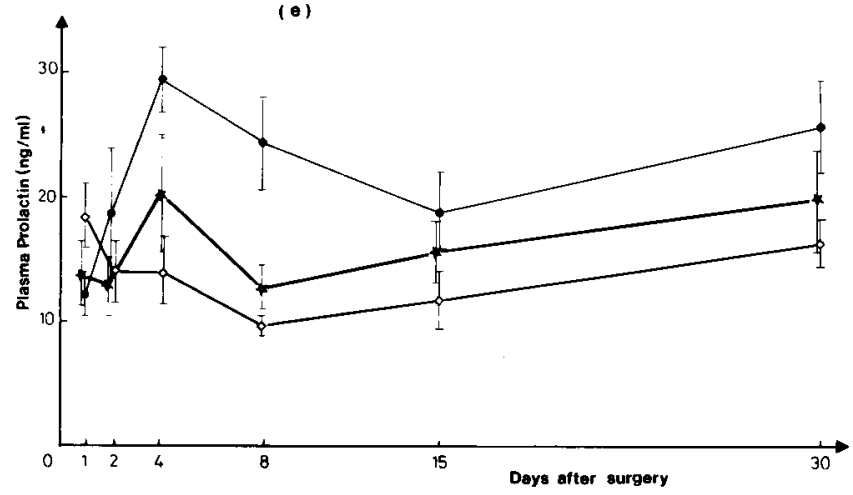

FIG. 1. - Plasma levels of $L H, F S H$ or PRL in adult male rats ofter surgical cryptorchidism (०-०), castration $(\star-\star)$ or sham operation (•-•). Standards are CNRS-LH Sx 1-1; NIAMDD FSH RP1 ; INRA-PRL (equivalent to 2 times the NIAMDD PRL-RP1). Error bars represent SEM.

Plasma and pituitary levels of FSH (figs. 1c-2d). - After castration, plasma FSH levels rose between days 1 and 30. Plasma FSH concentrations were always significantly greater $(P<0.01)$ in castrated than in sham-operated animals. In the cryptor- 
chid rats, plasma FSH levels were depressed at day 1 but increased from day 8 onwards $(P<0.001)$. A plateau was reached about 15 days after surgery. Plasma FSH levels in castrated and cryptorchid animals were about 5 or 2.5 -fold greater, respectively, than
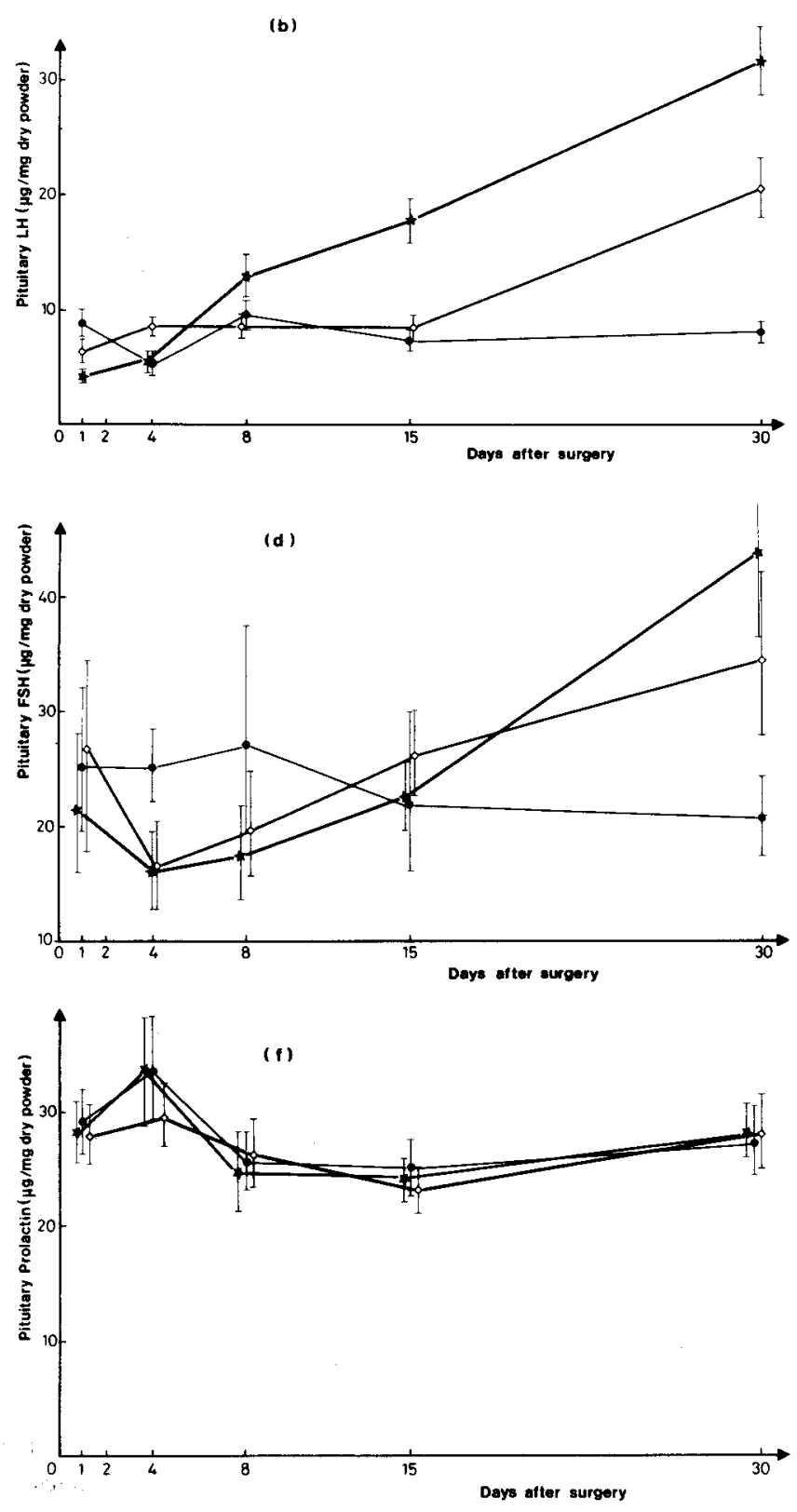

FIG. 2. - Pituitary LH, FSH or PRL content in adult male rats after surgical cryptorchidism $(\diamond-\diamond)$, castration $(\star-\star)$ or sham operation $(\bullet-)$. Error bars represent fiducial limits $(P=0.95)$. 
control values at day 30. Pituitary FSH concentrations were lower at day $4(P<0.05)$ in castrated and cryptorchid animals and did not increase before day 30 . At that time, the values were 2 or 1.7-fold greater than the control levels for the castrated and cryptorchid groups, respectively.

Plasma and pituitary levels of prolactin (figs. 1e-2f). - Plasma prolactin levels were depressed 8 days after castration $(P<0.01)$ and 4 and 8 days $(P<0.001)$ and 30 days $(P<0.05)$ after cryptorchidism when compared with sham-operated animals. Furthermore, from day 4 to 30 cryptorchid rats had significantly lower plasma prolactin levels than castrated animals $(P<0.05)$.

No significant variation was observed in pituitary prolactin concentration at any time after castration or cryptorchidism.

Plasma level of testosterone (fig. 3). - Twenty-four hours after casiration, plasma testosterone levels were significantly depressed $(P<0.001)$. These low levels remained unchanged befween days 1 and 8 , then increased significantly at day 15 and day 30 $(P<0.01$ and $P<0.001$, respectively, when compared with day-1 levels). Cryptorchidism induced a slight increase in plasma testosterone concentration during the first week after surgery (day $4: P<0.05$; day $8: P<0.01$ ). Thereafter, the plasma levels were indistinguishable from the control values.

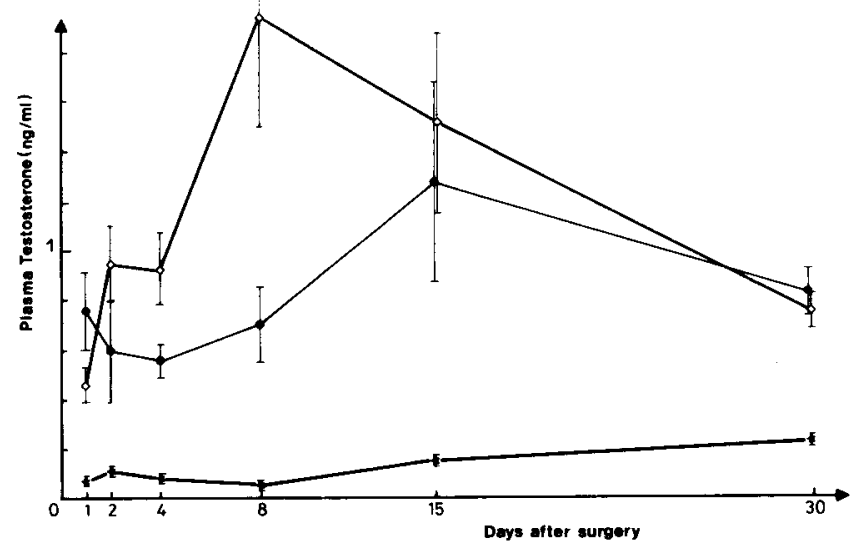

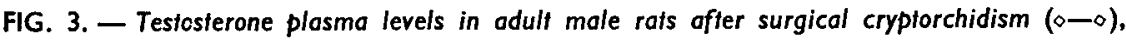
castration $(\star-\star)$ or sham operation (•-•). Error bars represent SEM.

Hypothalamic LH-RH content (fig. 4). - The hypothalamic LH-RH content decreased significantly $(P<0.01)$ at 4 days after castration and continued to fall until day 30. In contrast, no change was observed at any time after cryptorchidism.

\section{Discussion.}

The present results suggest that surgical cryptorchidism induces an increase in plasma testosterone during the first week after surgery. The increase at day 4 has not been found by some authors (Gupta ef al., 1975 ; Gomes and Jain, 1976), and its signifi- 


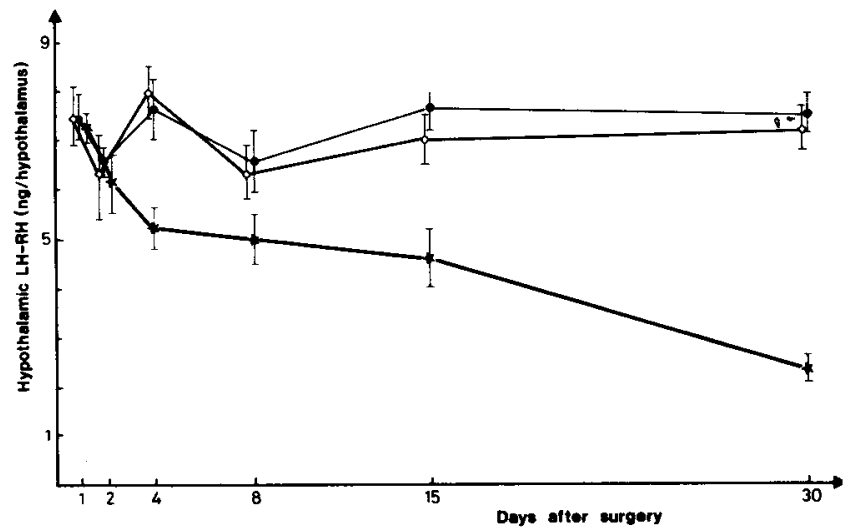

FIG. 4. - Hypothalamic LH-RH in adult male rots after cryptorchidism $(\diamond-)$, costration $(\star-\star)$ or sham operation (•-๑). Error bars represent SEM.

cance $(P<0.05)$ may be questioned, but there is good agreement with other investigators (Gomes and Jain, 1976 ; Hall and Gomes, 1975) concerning the reported rise at day $8(P<0.01)$. The latter authors, however, did not report the day 8 rise as significant.

In addition, it must be pointed out that Gomes and Jain (1976) have shown a significant increase of plasma testosterone in unilateral cryptorchid animals at day 4.

It is interesting that Gomes and Jain (1976) observed an augmentation of seminal vesicle weight in the cryptorchid rat 8 days after surgery. Although the increase in plasma testosterone levels observed around day 8 is difficult to explain it may be hypothesized that the higher FSH levels at day 8 augmented the $\mathrm{LH}$-induced testosterone response as shown previously by Johnson and Ewing (1971) and Chen, Payne and Kelch (1976). There is general agreement on the similarity of testosterone values between cryptorchid and intact controls in the ensuing period : around day 15 (Gomes and Jain, 1976 ; Hopkinson et al., 1979 ; above results) and around day 30 (Hopkinson ef al., 1979 ; de Kretser, Sharpe and Swanston, 1979 ; Kerr, Rich and de Kretser, 1979 ; above results).

The present results agree in general with previous reports (castration : e. $\dot{g}$. Amatayakul et al., 1971 ; Badger et al., 1978 ; cryptorchidism : Amatayakul ef al., 1971 ; Gomes and Jain, 1976 ; Hopkinson ef al., 1979) on the effects of castration or cryptorchidism on plasma and pituitary gonadotrophin levels in adult rats. The plasma and pituitary values of cryptorchid animals, for each of these hormones, lie somewhere between those of intact and castrated animals. However, a precise comparison reveals the following differences between the present and other results. In cryptochid animals, Amatayakul et al. (1971) indicated that plasma LH levels rise at day 2 after surgery, before those of FSH. On the contrary, our results, like those of Gomes and Jain (1976) and Hopkinson ef al. (1979), show that plasma FSH levels were affected before those, of LH. However, the significant rise in plasma FSH levels takes place at day 2 or 4 according to those authors, instead of at day 8 (present results). Stress or surgical pro- 
cedures may account for these differences, but the present values show a significant rise at day 4 (when compared to day-1 values for cryptorchid animals) instead of the day-4 values for sham-operated controls.

Furthermore, at 30 days after crypiorchidism and castration, an increase of both plasma and pituitary FSH and LH occurs which argues in favour of a rise in the synthesis of both gonadotrophins. The post-castration and post-cryptorchidism changes in pituitary FSH and LH observed in this study agree with earlier findings (Steinberger and Duckett, 1966 ; Amatayakul ef al., 1971).

Plasma prolactin levels in intact rats were found to be intermediate between those reported by Shin ef al. (1974) or Sharr ef al. (1975) (50-100 ng PRL-RP 1) and Ojeda, Jameson and McCann (1976) $(10 \mathrm{ng} / \mathrm{ml})$. Decapitation was chosen to avoid any stress response (Ojeda, Jameson and McCann, 1976), and the different levels observed by these authors may result from the younger rats used in the experiment. Nevertheless, the lowest plasma prolactin values at day 1 and day 2 , when compared to values between day 4 to day 30 for sham-operated animals, may be attributed to the anaesthesia. Effectively, Borrell, Piva and Martini (1978) reported a decrease of plasma prolactin levels $48 \mathrm{~h}$ after intraperitoneal administration of sodium pentobarbital to adult rats.

As shown previously (Shin ef al., 1974 ; Shaar et al., 1975), plasma prolactin levels were decreased slightly after castration. Cryptorchidism also depressed plasma prolactin levels, although this phenomenon was not observed by Ojeda, Jameson and McCann (1976). This, too, may be related to the age of the animals. Cryptorchidism (Ojeda, Jameson and McCann, 1976 ; Martinat, unpublished data) or castration (Martinat et al., 1979) of prepuberal rats has no effect on plasma prolactin levels. It has been shown that estradiol (Kalra ef al., 1973 ; Shin, 1979), testosterone (Kalra ef al., 1973 ; Shin et al., 1974) and aromatizable androgens, but not non-aromatizable androgens (Nolin et al., 1977 ; de La Heras and Negro-Vilar, 1979), are able to raise plasma prolactin levels. It is possible, therefore, that estradiol secretion may have been altered in the cryptorchid animals, as proposed by Hall and Gomes (1975). However, this does not explain why, in the present experiment, prolactin levels were more depressed in cryptorchid than in castrated animals.

The hypothalamic LH-RH content found in the adult rats in our experiment is very similar to that reported by Chen, Geneau and Meites (1977), Payne et al. (1977), Badger et al. (1978), Kalra and Kalra (1978) (6 to $8 \mathrm{ng}$ ). but somewhat different than that published by other authors (Chiappa and Fink, $1977: 12 \mathrm{ng}$; Shin and Howitt, 1974, 1975 : 15 to $20 \mathrm{ng}$; Root et al., $1975: 2 \mathrm{ng}$ ). The very short-term effect of castration, namely the augmentation of LH-RH hypothalamic content at day 1 or day 2 (Shin and Howitt, 1975), was not observed here. This is in agreement with the reports of Shin and Howitt (1976) and Chen et al. (1977). On the other hand, the decrease in hypothalamic LH-RH content known to occur around day 7 (Shin and Howitt, 1975 ; Root et al., 1975 ; Chen et al., 1977 ; Badger ef al., 1978), was observed from day 4 onwards. This 50 p. 100 decrease in hypothalamic content is associated with an increased LH-RH concentration in the hypophyseal portal blood and an increase in the synthesis of the neurohormone by the hypothalamus (Eskay, Mical and Porter, 1977 ; Moguilevsky, Enero and Szwaracfarb, 1974 ; Moguilevsky ef al., 1975 ; Kochman, Kochman and Domanski, 1977). The decreased LH-RH content appears to be related to the fall in circulating androgens because testosterone treatment of orchidectomized rats restored their level 
to that of the intact controls (Shin and Howitt, 1975 ; Chen ef al., 1977 ; Kalra and Kalra, 1978). Interestingly, cryptorchidism does not affect the hypothalamic LH-RH content for up to 30 days, further supporting the preceding data. This fact, coupled with the absence of any modification of plasma testosterone levels, strongly suggests that the LH secretion effects observed in the cryptorchid are largely due to modifications at the pituitary level.

Since the increase in plasma $\mathrm{LH}$ and $\mathrm{FSH}$ in response to $\mathrm{LH}-\mathrm{RH}$ was greater in cryptorchid than in intact animals (Hopkinson ef al., 1979), this hypothesis appears justified. In addition, it has been shown that media from cultures of mature rat seminiferous tubules, ovine testicular lymph and ovine RTF, respectively, are able to suppress, in a dose-related manner, both the basal secretion and the LH-RH stimulated secretion of FSH and LH by cultured rat pituitary cells (Eddie et al., 1978, 1979 ; de Jong, Smith and Van der Molen, 1979).

The mechanism through which plasma LH and FSH levels are raised in the cryptorchid rat could be as follows : inhibin (for recent reviews see de Jong, 1979 ; Blanc, 1980), a factor from the germinal epithelium, secreted in greater quantities in the normal than in the abdominal testis, is able to decrease the sensitivity of the pituitary to $\mathrm{LH}-\mathrm{RH}$ without affecting the hypothalamic LH-RH content.

Reçu en octobre 1980.

Accepté en janvier 1981.

Acknowledgements. - We wish to express our gratitude to Dr. Jutisz, Dr. Picaper and the NIAMDD, Bethesda, Maryland, for the generous supply of LH Sx 1-1, testosterone antiserum and FSH radioimmunoassay kits, respectively. We are also grateful to Dr. M. de Reviers for the statistical analysis and to Dr. J. Williams for help in preparing the English manuscript.

Résumé. Les concentrations plasmatiques de la LH, FSH, prolactine et testostérone, les contenus hypophysaires en gonadotropines et prolactine ainsi que le contenu hypothalamique en LH-RH ont éfé mesurés chez des rats mâles adultes à intervalles réguliers de 1 à 30 jours après la castration ou la cryptorchidie. La castration bilatérale entraîne, dès $24 \mathrm{~h}$, post-opératoire une diminution brutale des taux de testostérone. Au contraire, chez les animaux cryptorchides, on observe une augmentation (à J4 et J8) ou pas de différence par rapport aux niveaux des animaux témoins. Chez les rats castrés, une rapide augmentation de la $\mathrm{LH}$ ef de la FSH plasmatique intervient dès $\mathrm{J} 1$ et les niveaux de gonadotropines sont 7 et 5 fois plus élevés que ceux des contrôles à J30 respectivement pour la LH et la FSH. Chez les animaux cryptorchides, les changements observés dans les teneurs plasmatiques et hypophysaires en LH et en FSH sont comparables à ceux observés après castration mais interviennent plus tardivement et sont moins marqués.

Après castration ou cryptorchidie, aucun changement n'intervient dans les contenus pituitaires en prolactine. Par contre, les niveaux plasmatiques en prolactine sont significativement abaissés 8 jours post-castration et 4,8 et 30 jours post-cryptorchidie. Au niveau hypothalamique, on observe après castration une diminution progressive des taux de LH$\mathrm{RH}$, significative dès $\mathrm{J} 4$ et qui s'accentue jusqu'à $\mathrm{J} 30$. Au contraire, aucun changement n'intervient après cryptorchidie.

Le présent résultat indique qu'un facteur différent de la testostérone, associé avec la présence d'un épithélium séminifère actif, est impliqué dans la régulation des gonadotropines sans provoquer de changement dans les contenus hypothalamiques en LH-RH. 


\section{References}

AMATAYAKUL K., RYAN R., NOZUMI T., ALBERT A., 1971. A reinvestigation of testicular anterior pituitary relationships in the rat. I. Effects of castration and cryptorchidism. Endocrinology, 88, $872-880$.

BADGER T. M., WILCOX C. E., MEYER E. R., BELL R. D., CICERO T. J., 1978. Simultaneous changes in tissue and serum levels of luteinizing hormone, follicle-stimulating hormone and luteinizing hormone (follicle stimulating hormone releasing hormone) after castration in the male rat. Endocrinology, 102, 136-141.

BLANC M. R., 1980. L'inhibine. Reprod. Nutr. Dévelop., 20, 573-586.

BORRELL J., PIVA F., MARTINI L., 1978. Effect of pentobarbital on serum level of LH, FSH and prolactin in long-term ovariectomized rats. Neuroendocrinology, 27, 239-246.

CARATY A., de REVIERS M. M., PELLETIER J., DUBOIS M., 1980. Reassessment of radioimmunoassay of LRF in plasma and hypothalamic extracts of rats and rams. Reprod. Nutr. Dévelop., 20, 1489-1501.

CHEN H. T., GENEAU G., MEITES J., 1977. Effects of castration, steroid replacement and hypophysectomy on hypothalamic LH-RH and serum LH. Proc. Soc. exp. Biol. Med., 156, 127-131.

CHEN Y. I., PAYNE A. H., KELCH R. P., 1976. FSH stimulation of Leydig cell function in the hypophysectomized immature rat. Proc. Soc. exp. Biol. Med., 153, 473-475.

CHIAPPA S. A., FINK G., 1977. Releasing factor and hormonal changes in the hypothalamic-pituitarygonadotrophin and adrenocorticotrophin systems before and after birth and puberty in male, female and androgenized female rats. J. Endocr., 72, 211-224.

CLEGG E. J., 1963. Studies on artificial cryptorchidism : degenerative and regenerative changes in the germinal epithelium of the rat testis. J. Endocr., 27, 241-246.

CLEGG E. J., 1965. Studies on artificial cryptorchidism : the histological appearance of unilateral and bilateral abdominal testes in the rat. J. Endocr., 33, 269-278.

EDDIE L. W., BAKER H. W. G., DULMANIS A., HIGGINSON R. E., HUDSON B., 1978. Inhibin from cultures of rat seminiferous tubules. J. Endocr., 78, 217-234.

EDDIE L. W., BAKER H. W. G., HIGGINSON R. E., HUDSON B., 1979. A bioassay for inhibin using pituitary cell cultures. J. Endacr., 81, 49-60.

EMMENS C. W., 1948. Principles of biological assay. Chapman and Hall Lid., London.

ESKAY R. L., MICAL R. S., PORTER J. C., 1977. Relationship between luteinizing hormone concentration in hypophysial portal blood and luteinizing hormone release in intact, castrated and electrically-stimulated rats. Endocrinology, 100, 263-270.

GOMES W. R., JAIN S. K., 1976. Effect of unilateral and bilateral castration and cryptorchidism on serum gonadotrophins in the rat. J. Endocr., 68, 191-196.

GUPTA D., RAGER K., ZARZYCKI I., EICHNER M., 1975. Levels of luteinizing hormone, follicle stimulating hormone, testosterone and dihydrotestosterone in the circulation of sexually maturing intact male rats and after orchidectomy and experimental bilateral cryptorchidism. J. Endocr., 66, 183-193.

HALL R. W., GOMES W. R., 1975. The effect of artificial cryptorchidism on serum estrogen and testosterone levels in the adult male rat. Acta endocr., 80, 583-591.

HOPKINSON C. R. N., CHARI S., STURM G., HIRSCHAUSER C., 1979. Study of testicular feedback in male rats using artificial cryptorchidism as a model. Horm. Res., 10, 310-319.

JOHNSON B. H., EWING L. L., 1971. Follicle stimulating hormone and the regulation of testosterone secretion in rabbit testes. Science, 173, 635-637.

JONG F. H. de, 1979. Review : Inhibin factor artifact. Mol. cell. Endocr., 13, 1-10.

JONG F. H. de, SMITH S. D., Van der MOLEN H. J., 1979. Bioassay of inhibin-like activity using pituitary cells in vitro. J. Endocr., 80, 91-102.

KALRA P. S., FAWCETT C. P., KRULICH L., MCCANN S. M., 1973. The effects of gonadal steroids on plasma gonadotropins and prolactin in the rat. Endocrinology, 92, 1256-1268.

KALRA P. S., KALRA S. P., 1978. Effects of intrahypothalamic testosterone implants on LH-RH levels in the preoptic area and the medio-basal hypothalamus. Life Sci., 23, 65-68. 
KERR J. B., RICH K. A., KRETSER D. M. de, 1979. Alterations of the fine structure and androgen secretion of the interstitial cells in the experimentally cryptorchid rat testis. Biol. Reprod., 20, 409-422.

KOCHMAN K., KOCHMAN H., DOMANSKI E., 1977. Biosynthesis of the luteinizing hormone releasing hormone (LH-RH) in the rat hypothalamus. Acto physiol., 28, 353-358.

KRETSER D. M. de, SHARPE R. M., SWANSTON I. A., 1979. Alterations in steroidogenesis and human chorionic gonadotropin binding in the cryptorchid rat testis. Endocrinology, 105, 135138.

LAS HERAS F. de, NEGRO-VILAR A., 1979. Effect of aromatizable androgens and estradiol on prolactin secretion in prepuberal male rats. Arch. Androl., 2, 135-139.

MARTINAT N., HALL H., RAVAULT J. P., DUBOIS M. P., 1979. Purification of rat prolactin : development of an homologous radioimmunological assay and comparison with the NIAMDD system. Ann. Biol. anim. Bioch. Biophys., 19, 1771-1788.

MOGUILEVSKY J. A., ENERO M. A., SZWARCFARB B., 1974. Luteinizing hormone releasing hormone-biosynthesis by rat hypothalamus in vitro. Influence of castration. Proc. Soc. exp. Biol. Med., 147, 434-437.

MOGUILEVSKY J. A., SCACCHI P., DEBELJUK L., FAIGON M. R., 1975. Effect of castration upon hypothalamic luteinizing hormone releasing factor (LH-RF). Neuroendocrinology, 17, 189-192.

NOLIN J. M., CAMPBELL G. T., NANSEL D. D., BODGANOVE E. M., 1977. Does androgen influence prolactin secretion ? Endocr. Res. Communic., 4, 61-70.

OJEDA S. R., JAMESON H. E., MCCANN S. M., 1976. Plasma prolactin levels in maturing intact and cryptorchid male rats : development of stress response. Proc. Soc. exp. Biol. Med., 151, 310-315.

PAYNE A. H., KELCH R. P., MURONO E. P., KERLAN J. T., 1977. Hypothalamic pituitary and testicular function during sexual maturation of the male rat. J. Endocr., 72, 17-26.

ROOT A. W., REITER E. O., DUCKETT G. E., SWEETLAND M. L., 1975. Effect to short-term castration and starvation upon hypothalamic content of luteinizing hormone-releasing hormone in adult male rats. Proc. Soc. exp. Biol. Med., 150, 602-605.

SHAAR C. J., EUKER J. S., RIEGLE G. D., MEITES J., 1975. Effects of castration and gonadal steroids on serum luteinizing hormone and prolactin in old and young rats. J. Endocr., 66, 45-51.

SHIN S. H., 1979. Estradiol generates pulses of prolactin secretion in castrated male rats. Neuroendocrinology, 29, 270-275.

SHIN S. H., AIKEN R. B., ROBERTS R., HOWITT C., 1974. Effect of testosterone on serum prolactin in the castrated rat. J. Endocr., 63, 257-258.

SHIN S. H., HOWITT C. J., 1974. Acidic aqueous extraction of hypothalamic luteinizing hormone releasing hormone to study biological effects. Can. J. Physiol. Pharmac., 52, 754-758.

SHIN S. H., HOWITT C. J., 1975. Effect of castration on luteinizing hormone and luteinizing hormone releasing hormone in the male rat. J. Endocr., 65, 447-448.

SHIN S. H., HOWITT C. J., 1976. Effect of testosterone on hypothalamic LH-RH content. Neuroendocrinology, 21, 165-174.

SNEDECOR G. W., 1956. Statistical methods. The lowa State Univ. Press, Ames, lowa, USA, 5 e Ed.

STEINBERGER E., DUCKETT G. E., 1966. Pituitary « total » gonadotrophins, FSH and LH in orchidectomized or cryptorchid rats. Endocrinology, 79, 912-920.

SWERDLOFF R. S., WALSH P. C., JACOBS H. S., ODELL W. D., 1971. Serum LH and FSH during sexual maturation in the male rat : effect of castration and cryptorchidism. Endocrinology, 88, 120-128.

VIGUIER-MARTINEZ M. C., HOCHEREAU-REVIERS M. T. de, 1977 . Comparative action of cyproterone and cyproterone acetate on pituitary and plasma gonadotropin levels, the male genital tract and spermatogenesis in the growing rat. Ann. Biol. anim. Bioch. Biophys., 17, 1069-1076. 